\title{
Evaluation of the Methanolic Rhizome Extract of Anchomanes difformis for Analgesic and Antipyretic Activities
}

\author{
Eke Ifeanyi Gabriel*, Obioha Felix Chidiebere, Anaga, Aruh Ottah \\ Drug Discovery Laboratory, Pharmacology Unit, Department of Veterinary physiology and pharmacology, University of Nigeria \\ Nsukka, 410001 Enugu State Nigeria \\ *Corresponding author E-mail: ekeig02@yahoo.com
}

\begin{abstract}
Objectives: To evaluate rhizomes extract of Anchomanes difformis (extract) for analgesic, antipyretic and local anesthetic activities.

Methods: Extract was prepared by cold maceration in 70\% methanol. Oral acute toxicity was evaluated and LC50 determined. Extract at 100, 250, 500 and $1000 \mathrm{mg} / \mathrm{kg}$ was tested against Sodium pentobarbital (SPB)-induced narcosis, acetic acid (AC)-induced abdominal constrictions, formalin-induced paw-licking (FIPL) and brewer's yeast-induced pyrexia. Local anesthetic effect tested using twitch response test in guinea pig at $0.33,0.66$ and $1 \%$ extract.

Results: Mice tolerated extract up to $4000 \mathrm{mg} / \mathrm{kg}$. LC50 was $589.13 \mathrm{ppm}$. Induction and sleeping times of SPB were significantly $(\mathrm{p}<0.05)$ decreased at 500 and $1000 \mathrm{mg} / \mathrm{kg}$ and 250,500 and $1000 \mathrm{mg} / \mathrm{kg}$ respectively compared with SPB. Abdominal constriction significantly $(\mathrm{p}<0.05)$ decreased at $500 \mathrm{mg} / \mathrm{kg}$ compared with negative control. There was significant $(\mathrm{p}<0.05)$ decrease in paw licking in both 1st and 2nd phases of FIPL at 250 and $500 \mathrm{mg} / \mathrm{kg}$ and 500 and 1000 $\mathrm{mg} / \mathrm{kg}$ respectively compared with negative control. Rectal temperature significantly $(\mathrm{p}<0.05$ ) decreased at $1000 \mathrm{mg} / \mathrm{kg}$ $1 \mathrm{~h}$ post-administration compared with aspirin $(100 \mathrm{mg} / \mathrm{kg})$ and at $2-4 \mathrm{~h}$ compared with negative control. Local anesthetic effect was concentration-dependent.
\end{abstract}

Conclusion: The extract showed promising analgesic, antipyretic and local anesthetic effects.

Keywords: Analgesic, Anchomanes difformis, local anesthetic, pyrexia, sodium pentobarbital-induced narcosis.

\section{Introduction}

Pain is the most common reason for physician consultation worldwide [1]. It is a major symptom in many medical conditions, and can significantly interfere with a person's quality of life and general functioning [2]. Many non steroidal antiinflammatory drugs and opiate analgesics have been used over the years in the clinical management of pain, but they are not without serious side effects. Therefore there is the need for more effective and safer alternatives. Many plant preparations have been used especially in developing countries for management of pain syndromes and users of such preparations attest to their effectiveness, but surprisingly no scientific data exists for the effectiveness and safety of most of these preparations. Preparations of Anchomanes difformis is one of such. Anchomanes difformis is a tropical herb indigenous to Nigeria and Cameroun. It flourishes well in moist shady areas as occurs in southern parts of Nigeria [3]. Different parts of the plant are used for various conditions. The rhizomes are used as rubefacients and vesicants, whole plant as a powerful purgative and as antidote to poisons and the tuber as abortifacient, pain reliever and as laxative [4]. A. difformis extracts showed trypanocidal activity against Trypanosoma brucei brucei and T. congolense [5]. Aka et al [3] reported the presence of flavonoids, tannins and glycosides in the rhizome of $A$. difformis. Due to the various medicinal potential of different parts of this plant, the analgesic and antipyretic effects of the rhizomes of $A$. difformis were studied

\section{Materials and methods}

\subsection{Plant material and extraction}

The rhizomes of A, difformis were collected in August 2009 from Ichi in Oru west Local Government Area, Imo state Nigeria and were identified by Mr. A. E. Ozioko of the Biodiversity and conservation program Nsukka, Enugu state 
Nigeria. A voucher sample (UN/BD.3950.09) was kept in the herbarium of Department of Botany University of Nigeria. The rhizomes were cut into smaller pieces and dried under shed at temperature range $25-27^{\circ} \mathrm{C}$. The dried matter was pulverized to a coarse powder (mesh size, $1.00 \mathrm{~mm}$ ). The coarse powder $(200 \mathrm{~g})$ was extracted by cold maceration in $70 \%$ methanol with intermittent shaking for 48 hours. The extract was filtered with Whatman No. 1 filter paper and concentrated in vacuo to dryness using rotary evaporator and will be referred to as the "extract" subsequently. The percent yield $(\mathrm{w} / \mathrm{w})$ of the extract was calculated using the formula below:

Weight of the extracted material $X 100$

Weight of starting plant material

\subsection{Animals}

Adult male guinea pigs (178-205 g), white albino mice of both sexes (20-33 g) from the laboratory animal unit of the faculty of Veterinary Medicine, University of Nigeria Nsukka were kept in stainless steel cages and fed ad libitum with standard laboratory animal chow (vital feed ${ }^{\circledR}$ ), except were fasting was required. They were maintained in accordance with the recommendation in the Guide for Care and Use of Laboratory Animals (DHH, NIH Publication No. 85-23, 1985). The experiments were conducted with the permission of the Institution's Animal Ethics Committee.

\subsection{Acute toxicity test}

The up and down method [6] was used. Twelve mice fasted for $16 \mathrm{~h}$ were grouped into 6 of 2 per group and were dosed $300,750,1500,3000,3500$ and $4000 \mathrm{mg} / \mathrm{kg}$, b.w. of the extract. They were monitored for $24 \mathrm{~h}$ for signs of toxicity and mortality.

\subsection{Brine shrimp lethality test (BSLT)}

The effect of the extract on brine shrimps was evaluated using the method of Mclaughlin et al [7]. Briefly, brine shrimp eggs were hatched in culture tank containing sea water under bright light for $48 \mathrm{~h}$. Ten nauplii were counted into bijou bottles in triplicates and were incubated with graded concentrations of the extract (10, 100 and $1000 \mathrm{ppm})$ at room temperature for $24 \mathrm{~h}$. The mean surviving nauplii was determined for each concentration of the extract and compared with that of the control. The result was analyzed using probit analysis (minitab for windows release 12.21) to determine the LC50 at $95 \%$ confidence interval.

\subsection{Effect of the extract on sodium pentobarbital (SPB)-induced narcosis in mice}

The effect of the extract on sleeping time was determined by intraperitoneal (IP) administration of SPB ( $35 \mathrm{mg} / \mathrm{kg} \mathrm{b.w.)}$ alone to mice in group 1, Mice in groups 2-5 were treated with $100,250,500$ and $1000 \mathrm{mg} / \mathrm{kg} \mathrm{b.w.} \mathrm{of} \mathrm{the} \mathrm{extract} \mathrm{per} \mathrm{os,}$ respectively $30 \mathrm{~min}$ before IP administration of $35 \mathrm{mg} / \mathrm{kg}$, b.w. SPB to each. The induction time was calculated as the interval between SPB injection and loss of righting reflex, while sleeping time was calculated as the interval between the loss of righting reflex and time of regaining righting reflex for each mouse [8,9].

\subsection{Antinociceptive test}

\subsubsection{Effect of the extract on the acetic acid (AC)-induced abdominal constriction}

The abdominal constriction test as described by Dambisya and Lee [10] was used to investigate the analgesic effect of $A$. difformis. Glacial AC (Sigma-Aldrich Laborchemikalien GMBH Germany) prepared as 0.7\% (v/v) solution in distilled water $(10 \mathrm{ml} / \mathrm{kg}$, b.w.) was used to induce pain by IP route $30 \mathrm{~min}$ after pretreatment with either indomethacin or the extract. Group 1 mice were given $10 \mathrm{ml} / \mathrm{kg}$ b.w. distilled water per os and served as the negative control, group 2 received indomethacin $(10 \mathrm{mg} / \mathrm{kg}$ b.w. per os $)$, while groups 3-5 received the extract at 250, 500 and $1000 \mathrm{mg} / \mathrm{kg}$ b.w. per os respectively. The abdominal constrictions resulting from the administration of AC consisted of contraction of the abdominal muscles and stretching of the hind limbs [11]. The number of abdominal constrictions was counted for each mouse $5 \mathrm{~min}$ after administration of AC over a period of $30 \mathrm{~min}$. the degree of antinociception was calculated using the formula described by Dambisya and Lee [10] as follows:

$$
\left[\frac{(X-Y)}{X}\right] \times 100
$$

Where $\mathrm{X}=$ mean number of constrictions by the negative control, $\mathrm{Y}=$ mean number of constrictions by any of the test groups. 


\subsubsection{Effect of the extract on formalin-induced paw licking (FIPL)}

The paw licking and lifting test as described by Collen et al [12] was also used to investigate the antinociceptive effect of the extract. Twenty five white albino mice were divided into 5 groups of 5 and treated as follows: group 1 received $10 \mathrm{ml} / \mathrm{kg}$ b.w. distilled water and served as the negative control, group 2 received $10 \mathrm{mg} / \mathrm{kg} \mathrm{b.w.} \mathrm{indomethacin} \mathrm{and}$ served as the positive control, while groups 3-5 received 250, 500 and $1000 \mathrm{mg} / \mathrm{kg} \mathrm{b.w}$. of the extract per os respectively. Formalin $(50 \mu \mathrm{l})(5 \%, 1.85 \%$ formaldehyde solution) was injected subcutaneously into the plantar surface of the right hind limb paw, 30 min post administration of drug and extract and the number of paw licking/lifting for each mouse was counted and recorded in two phases; first phase (0-5 min) and second phase (25-30 min).

\subsection{Antipyretic effect}

\section{Effect of the extract on brewer's yeast-induced pyrexia (BYP)}

The method described by Panthong et al [13] was adopted for the determination of antipyretic activity of the extract in mice. Pyrexia was induced in the mice (fasted for $18 \mathrm{~h}$, but had water ad libitum) by administration of $15 \%$ (w/v) of brewer's yeast in $0.9 \%$ saline solution at a dose of $10 \mathrm{mg} / \mathrm{kg}$ b.w. subcutaneously. Following the injection, the site was massaged in order to spread the suspension uniformly under the skin. The rectal temperatures of the mice were measured with thermometer (Panamedic Corporation, Cheonan Choongnam, Korea) before and $18 \mathrm{~h}$ after administration of brewer's yeast. Only mice that showed increased temperature not less than $0.5^{\circ} \mathrm{c}$ were selected for the test. Group 1 mice received $10 \mathrm{ml} / \mathrm{kg}$, b.w. distilled water per os, group 2 received $100 \mathrm{mg} / \mathrm{kg}$ b.w. aspirin per os, and groups 3-5 received 250,500 and $1000 \mathrm{mg} / \mathrm{kg}$ b.w. of the extract per os respectively. A latency period of $30 \mathrm{~min}$ was allowed before the rectal temperatures of the mice were recorded every hour over a period of $4 \mathrm{~h}$.

\subsection{Local anesthetic test}

\section{Twitch response test (TRT)}

The local anesthetic effect of the extract was investigated using the method described by Anaga et al [9]. The lower back of a guinea pig was shaved $24 \mathrm{~h}$ before the test. Three different concentrations of the extract $(0.33,0.66$ and $1 \%)$ and xylocain $(0.033,0.066$ and $0.1 \%)$ were used. A volume of $0.25 \mathrm{ml}$ each of the concentrations of the extract and xylocain were injected intradermally to form wheals. Therefore six different sites on the lower back of the guinea pig were used. Five minutes after the injection, the sensitivity of the site was tested by pricking lightly with a needle six times at each of the injection sites and as control; a site far away from injection sites was pricked. The response at the site of injection indicated the degree of desensitization which was expressed as the number of negative responses i.e. of failure to twitch; 6/6 indicates maximum anesthesia while 0/6 indicates no anesthesia. The test was repeated at 5 min intervals for a period of $30 \mathrm{~min}$ after the injection. The total score for each group was summed up and expressed as the total number of negative responses out of the 36 possible responses and expressed as percent anesthesia.

\subsection{Statistical analysis}

Data obtained were presented as mean \pm standard error of mean and analyzed using one way analysis of variance. Variant means were separated post hoc using Duncan multiple range test and significance was accepted at $\mathrm{p}<0.05$. Percentages were also calculated where necessary.

\section{Results}

\subsection{Extract yield, acute toxicity and LC50}

The methanol rhizome extract of Anchomanes difformis yielded 2.59\% w/w dry matter. Mice tolerated the extract up to $4000 \mathrm{mg} / \mathrm{kg}$, b.w. which was the highest dose used for acute toxicity, but there was in appetence, CNS depression and clustering together. Brine shrimp lethality test as shown in table 1, gave the LC50 of the extract to be 589.13 ppm at $95 \%$ confidence interval.

\subsection{Effect of extract on SPB-induced narcosis}

The effect of the extract on SPB-induced narcosis is presented in figs. $1 \& 2$ respectively. Induction time of SPB was significantly $(\mathrm{p}<0.05)$ decreased at 500 and $1000 \mathrm{mg} / \mathrm{kg}$, b.w. of the extract when compared with SPB alone. More so 
the sleeping time was significantly $(\mathrm{p}<0.05)$ increased at 250,500 and $1000 \mathrm{mg} / \mathrm{kg}$, b.w. of the extract compared with SPB alone.

Table.1: Effect of the methanol extract of the rhizomes of A. difformis on brine shrimps

\begin{tabular}{cclll}
\hline \multicolumn{2}{c}{ Groups } & No. dead & No. alive & \% mortality \\
\hline A & 1 & Nil & 10 & 0 \\
& 2 & nil & 10 & \\
& 3 & nil & 10 & 0 \\
B & 1 & Nil & 10 & \\
& 2 & nil & 10 & 13.3 \\
& 3 & nil & 10 & \\
C & 1 & 2 & 8 & 93.3 \\
& 2 & 1 & 9 & \\
& 3 & 1 & 9 & \\
\hline
\end{tabular}

A: sea water, B: extract (10 ppm), C: extract (100 ppm), D: extract (1000 ppm)

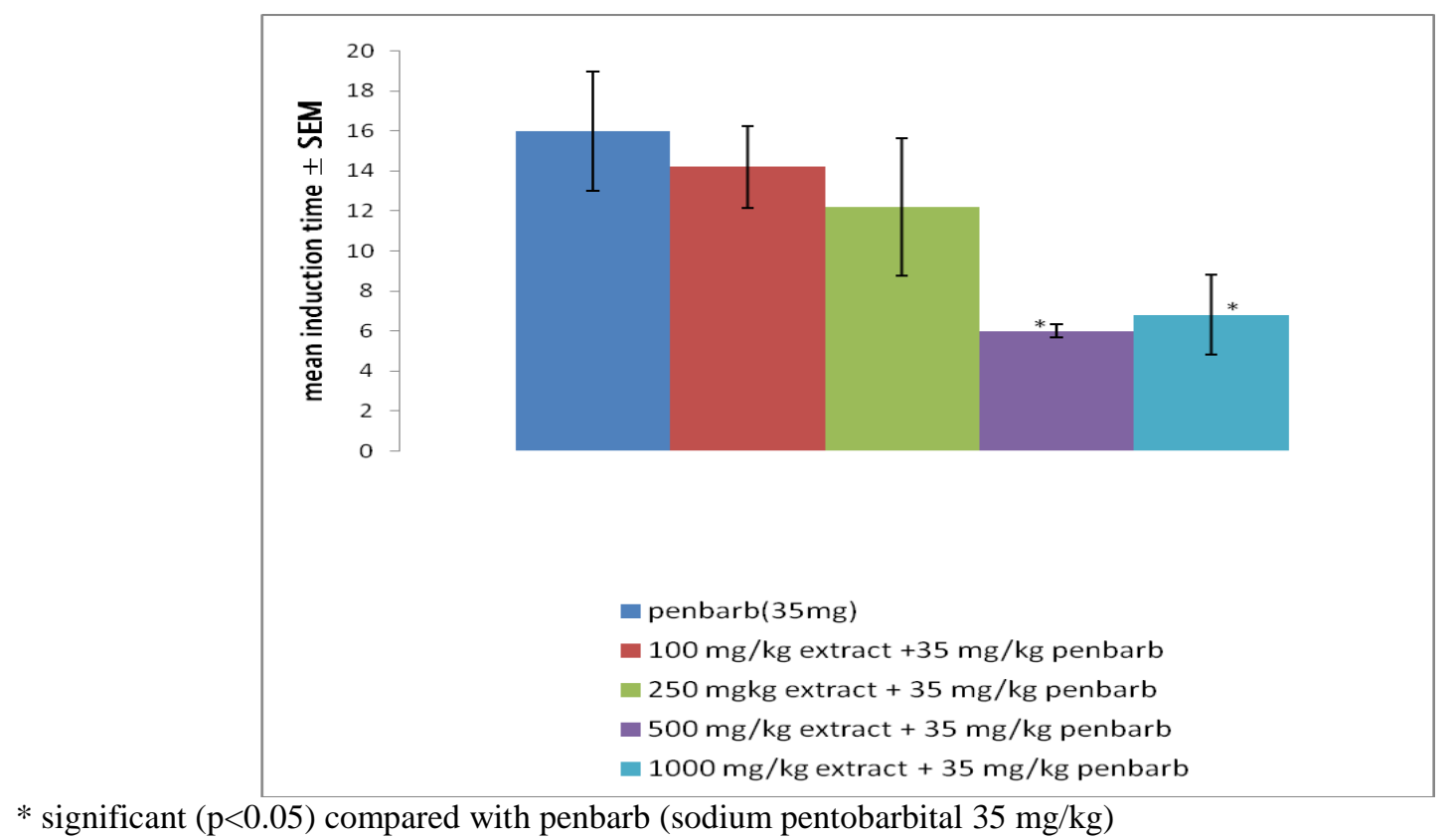

Fig.1: Effect of the methanol rhizome extract of A. difformis on induction time of sodium pentobarbital in mice

\subsection{Effect of extract on acetic acid-induced abdominal constriction}

The effect of the extract on the Acetic acid-induced abdominal constriction as presented in table 2 showed that 500 $\mathrm{mg} / \mathrm{kg}$ b.w. of the extract significantly $(\mathrm{p}<0.05)$ decreased the number of abdominal constriction when compared with the negative control. However there was no significant ( $\mathrm{p}>0.05$ ) difference between $10 \mathrm{mg} / \mathrm{kg}$ indomethacin and 500 $\mathrm{mg} / \mathrm{kg}$ b.w. extract.

\subsection{Effect of extract on formalin-induced paw licking/lifting}

The extract at 250 and $500 \mathrm{mg} / \mathrm{kg}$, b.w. significantly $(\mathrm{p}<0.05)$ decreased the number of paw licking and lifting in the first phase (fig. 3) of formalin-induced nociception when compared with the negative control, while in the second phase (fig. 4), 500 and $1000 \mathrm{mg} / \mathrm{kg}$, b.w. extract significantly $(\mathrm{p}<0.05)$ decreased the number of paw licking and lifting compared with the negative control. In both phases there were no significant ( $p>0.05)$ difference between the effective doses of the extract and indomethacin $(10 \mathrm{mg} / \mathrm{kg})$. The degree of antinociception is presented as percentages in table 3 . It shows that the extract at $500 \mathrm{mg} / \mathrm{kg}$ in both phases produced the strongest effect ( 60 and $97 \%$ respectively) compared with indomethacin (33 and $76 \%$ respectively). 


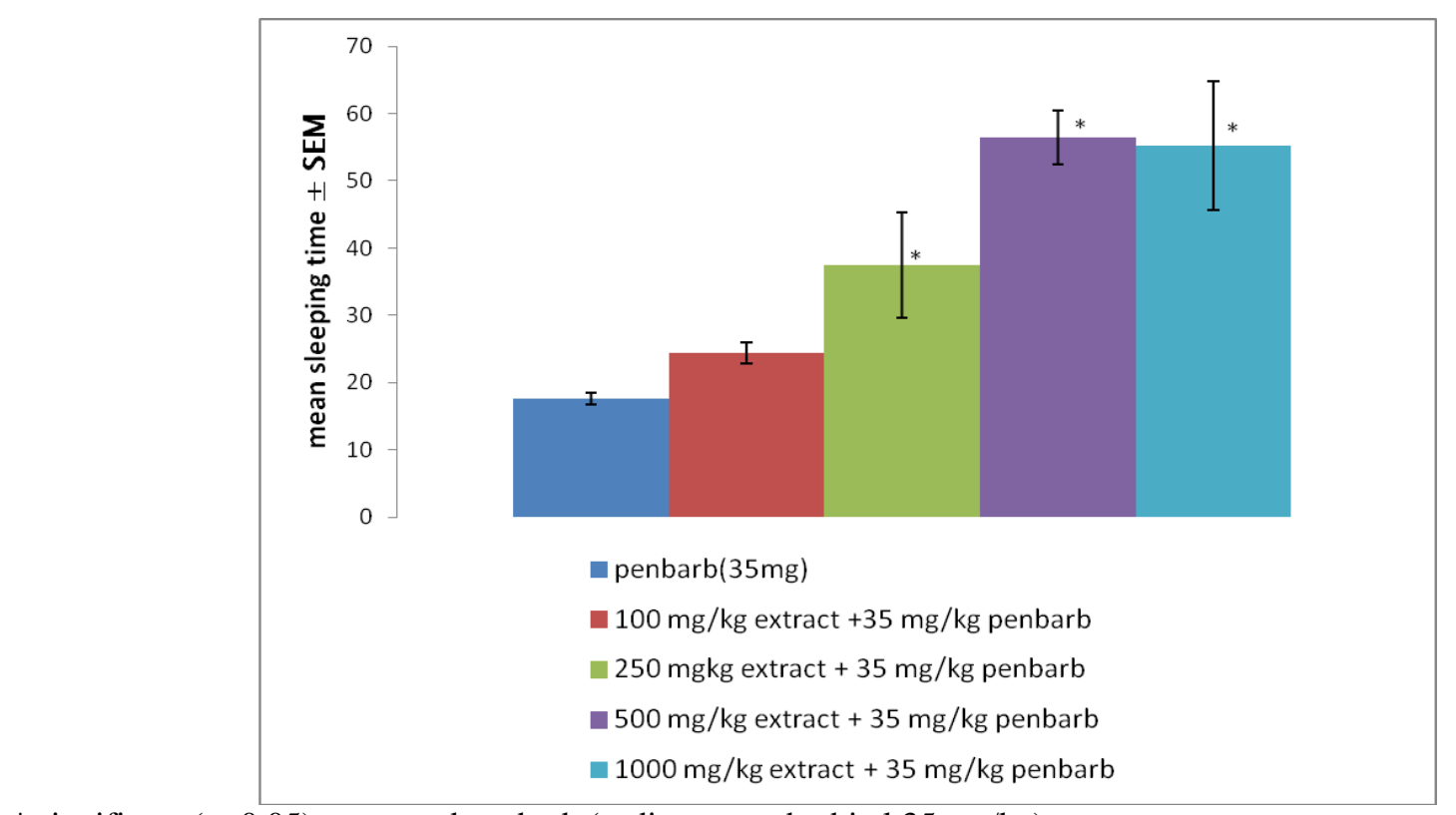

* significant $(\mathrm{p}<0.05)$ compared penbarb (sodium pentobarbital $35 \mathrm{mg} / \mathrm{kg}$ )

Fig.2: Effect of the methanol rhizome extract of A. difformis on the sodium pentobarbital-induced sleeping time in mice

Table.2. Effect of the methanol rhizome extract of A. difformis on acetic acid-induced abdominal constriction in mice

\begin{tabular}{lll}
\hline Groups & Mean number of abdominal constrictions & \% inhibition of abdominal constrictions \\
\hline $\mathrm{A}(10 \mathrm{ml} / \mathrm{kg}$ b.w. dist. Water $)$ & $67.00 \pm 11.48$ & 0.00 \\
$\mathrm{~B}(10 \mathrm{mg} / \mathrm{kg}$ b.w. indomethacin $)$ & $32.80 \pm 4.19^{*}$ & 51.00 \\
$\mathrm{C}(250 \mathrm{mg} / \mathrm{kg}$ b.w. extract $)$ & $53.40 \pm 9.70$ & 20.30 \\
$\mathrm{D}(500 \mathrm{mg} / \mathrm{kg}$ b.w. extract $)$ & $41.20 \pm 2.06^{*}$ & 38.51 \\
$\mathrm{E}(1000 \mathrm{mg} / \mathrm{kg}$ b.w. extract $)$ & $48.40 \pm 4.07$ & 27.76 \\
\hline
\end{tabular}

Mean \pm SEM $^{*}$ is significant $(\mathrm{P}<0.05)$ compared with $10 \mathrm{ml} / \mathrm{kg}$ distilled water.

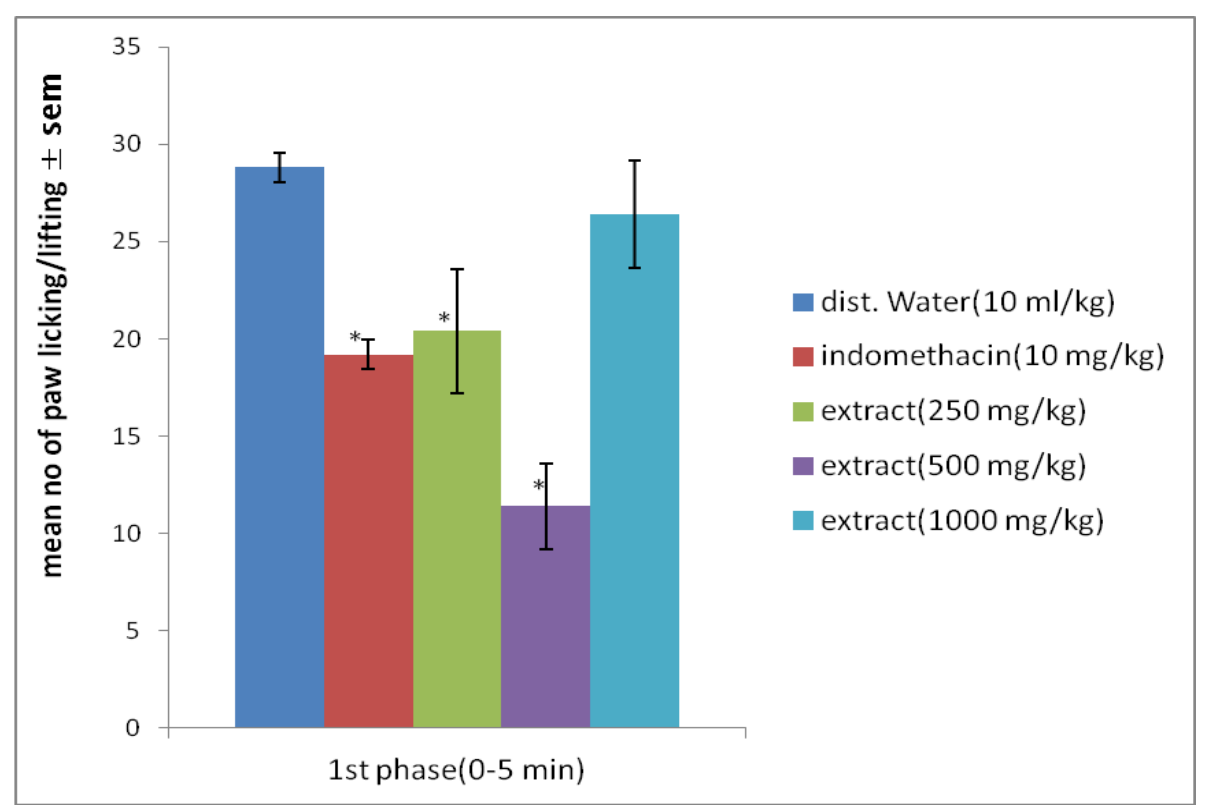

* significant $(\mathrm{p}<0.05)$ compared with $10 \mathrm{ml} / \mathrm{kg}$ dist. water

Fig.3: Effect of the methanol rhizome extract of A. difformis on the first phase of formalin-induced nociception in mice 


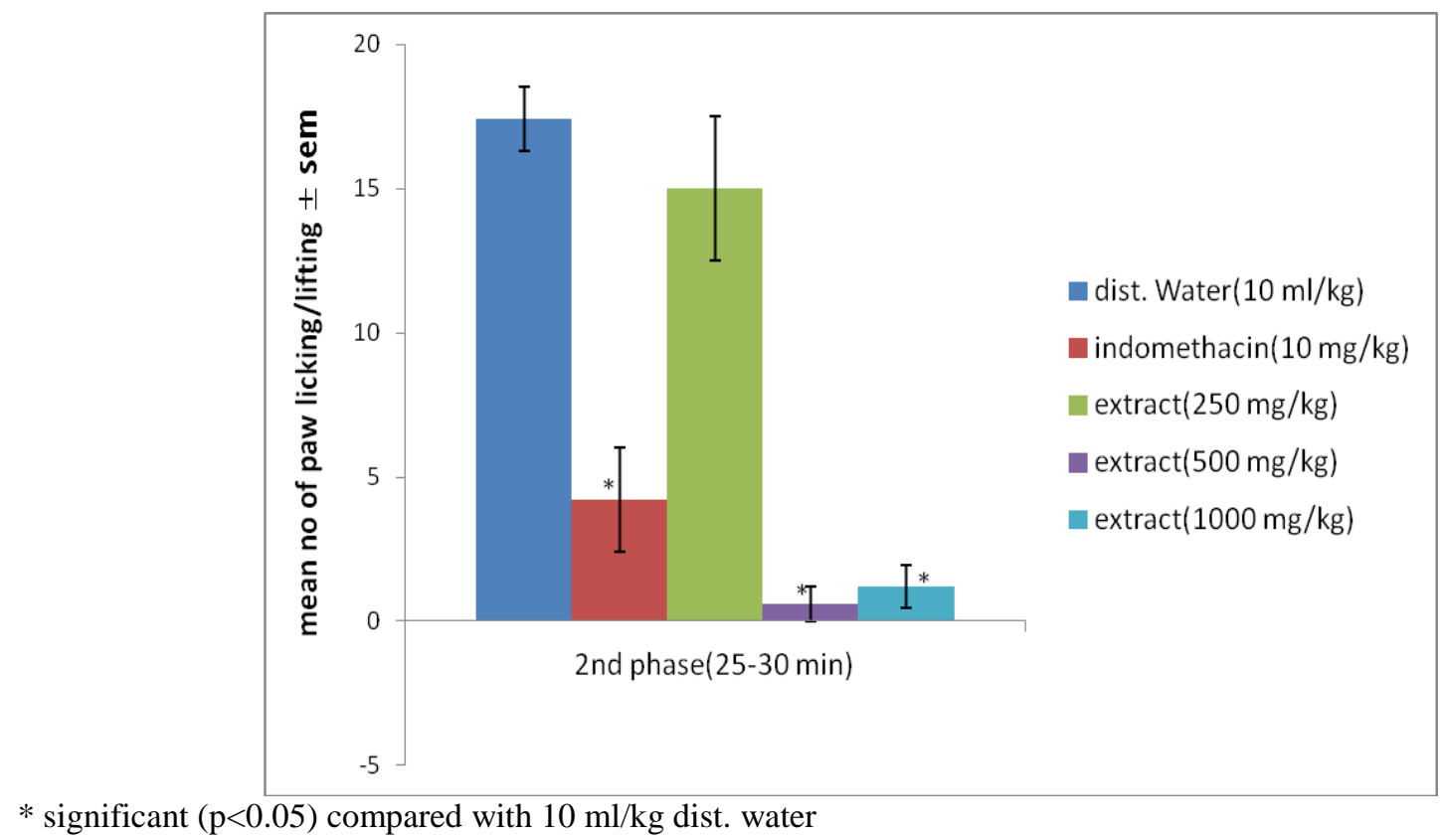

Fig.4 Effect of the methanol rhizome extract of A. difformis on the second phase of formalin-induced nociception in mice

Table 3 Percentage inhibition of formalin-induced nociception in mice

\begin{tabular}{lll}
\hline & Percentage inhibition of paw licking & \\
\hline Groups & 1 stphase & 2nd phase \\
$10 \mathrm{ml} / \mathrm{kg}$ dist.water & 0.00 & 0.00 \\
$10 \mathrm{mg} / \mathrm{kg}$ indomethacin & 33.00 & 76.00 \\
$250 \mathrm{mg} / \mathrm{kg}$ extract & 29.00 & 14.00 \\
$500 \mathrm{mg} / \mathrm{kg}$ extract & 60.00 & 97.00 \\
$1000 \mathrm{mg} / \mathrm{kg}$ extract & 8.00 & 93.00 \\
\hline
\end{tabular}

\subsection{Effect of extract on brewer's yeast-induced pyrexia}

Figure 5 shows the effect of the extract on brewer's yeast-induced pyrexia. It shows that $1000 \mathrm{mg} / \mathrm{kg} \mathrm{b.w}$. significantly $(\mathrm{p}<0.05)$ decreased rectal temperature $1 \mathrm{~h}$ post-administration when compared with both $10 \mathrm{ml} / \mathrm{kg}$ distilled water and $100 \mathrm{mg} / \mathrm{kg}$ aspirin. There was also significant $(\mathrm{p}<0.05)$ decrease in the rectal temperatures at 2,3 and $4 \mathrm{~h}$ when compared with $10 \mathrm{ml} / \mathrm{kg}$ distilled water.

\subsection{Effect of extract on the twitch response test in guinea pig}

In the twitch response test (table 3), the extract produced a concentration-dependent local anesthetic effect, however xylocain at one tenth the concentration of the extract was more effective.

\begin{tabular}{ll} 
& Table.4: Local anesthetic effect of the methanol rhizome extract of A. difformis in guinea pig \\
\hline Concentration $(\%)$ & Percent local anesthesia \\
\hline Xylocain $(0.033)$ & 86.11 \\
Xylocain (0.066) & 88.89 \\
Xylocain (0.1) & 100.00 \\
Extract $(0.33)$ & 22.22 \\
Extract (0.66) & 27.78 \\
Extract (1) & 50.00 \\
\hline
\end{tabular}




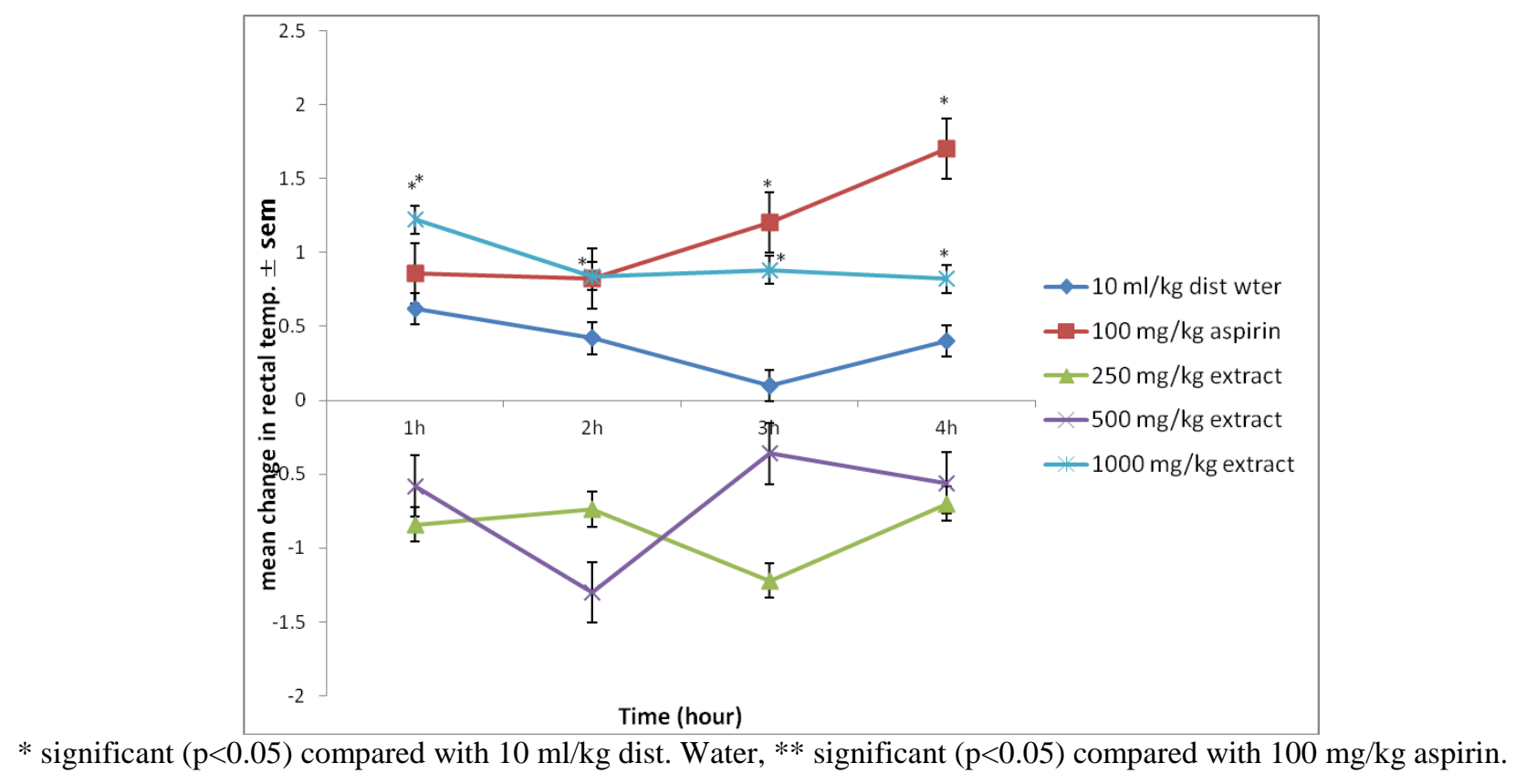

Fig.5: Effect of the methanol rhizome extract of A. difformis on the brewer's yeast-induced pyrexia in mice

\section{Discussion}

Here we showed that the methanol extract of the rhizome of A. difformis has wide safety margin as there was no mortality in mice dosed with the extract up to $4000 \mathrm{mg} / \mathrm{kg} \mathrm{b.w.} \mathrm{per} \mathrm{os.} \mathrm{The} \mathrm{extract} \mathrm{was} \mathrm{also} \mathrm{shown} \mathrm{to} \mathrm{contain} \mathrm{potent}$ bioactive principles as the LC50 was found to be $589.13 \mathrm{ppm}$, therefore the EC50 was approximated to be one tenth of the LC50; (58.91 ppm) [7]. The effect of the extract on the SPB-induced narcosis showed that the extract enhanced the effect of SPB as it significantly reduced the induction time of SPB at the doses of 500 and $1000 \mathrm{mg} / \mathrm{kg}$, b.w. and significantly prolonged the sleeping time at the doses of 250,500 and $1000 \mathrm{mg} / \mathrm{kg} \mathrm{b}$.w. This shows that the extract depresses the CNS and possibly like SPB enhances the action of GABA in the CNS [14]. Pain represents a series of reactions which include specialized and non-specialized tissue, psychological and cognitive reactions to painful stimuli [15]. Pain can be differentiated into visceral and somatic types for purpose of studying antinociceptive activity [16]. Visceral pain is perceived as a diffuse and burning sensation, while somatic is localized and sharp. Acetic acid-induced abdominal constriction is used to evaluate superficial and visceral pains [17]. It has also been used to screen for both peripheral and centrally acting analgesics. The abdominal constriction is associated with the sensitization of nociceptors to prostaglandins [18]. The number of abdominal constriction reflects the intensity of the pain, thus the higher the number of abdominal constriction, the higher the intensity of the pain and vice versa. The significant reduction in the number of abdominal constriction at $500 \mathrm{mg} / \mathrm{kg}$ b.w. of the extract suggests that the extract is capable of reducing the sensitivity of nociceptors to prostaglandins. Injection of formalin into the planter surface of the hind paw induces a biphasic pain response; the first phase is marked by paw lifting or licking and lasts for about 5 min and arises as a result of chemical stimulation of nociceptors [12]. The mediators involved are substance P and bradykinin. There is a transient decrease in this behavior and then the second phase which lasts about 30 min follows. The second phase is proposed to result from activity-dependent sensitization of CNS neurons within the dorsal horn and histamine and prostaglandins have been implicated as mediators involved [12]. Many analgesics, including non-steroidal antiinflammatory drugs, morphine, and gabapentin inhibit only Phase II responses while local anesthetics inhibit phase I [12]. The number of paw licking/lifting reflects the intensity of the pain response, the higher the number of paw licking/lifting, the higher the intensity of the pain. The reduction in the number of paw licking/lifting at 250 and $500 \mathrm{mg} / \mathrm{kg}$ of the extract in the first phase suggests that the extract is capable of inhibiting painful stimuli emanating from chemical stimulation of nociceptors. At the second phase of the formalin-induced nociception, the extract exhibited a more dramatic decrease in the number of paw licking/lifting at higher doses of 500 and $1000 \mathrm{mg} / \mathrm{kg} \mathrm{b}$.w. and these effects were higher than that of indomethacin $(10 \mathrm{mg} / \mathrm{kg} \mathrm{b} . \mathrm{w})$. This effect suggests that the extract was capable of desensitizing the CNS neurons within the dorsal horn and is consistent with the effect of the extract on the SPB-induced sleep, were there was enhanced depression of the CNS. The result also suggests inhibition of histamine and prostaglandin as inflammatory mediators. Fever is usually sequelae to tissue injury, inflammation or infection. Fever occurs when there is a disturbance of the hypothalamic heat regulatory center due to production of prostaglandin $\mathrm{E}$ in the hypothalamus [14]. The extract at the 
highest dose used (1000 mg/kg, b.w) progressively decreased the brewer's yeast-induced pyrexia throughout the period of the experiment, indicating active inhibition of prostaglandin E production in the hypothalamus. Local anesthetics act by blocking the initiation and propagation of action potentials by preventing the voltage-dependent increase in $\mathrm{Na}+$ conductance in two ways; by acting non-specifically on membrane through surface active effect and by specifically plugging $\mathrm{Na}+$ channels [14]. The extract produced a concentration dependent local anesthetic effect, indicating membrane stabilizing effect and possibly inhibition of $\mathrm{Na}+$ channels.

\section{Conclusion}

Our study shows that the methanol extract of the rhizome of A. difformis has promising analgesic and antipyretic properties acting peripherally possibly through inhibition of prostaglandins and centrally in the CNS. The extract also showed local anesthetic effect. These properties of the extract validate its use as analgesic in Nigeria.

\section{References}

[1] Turk DC, Dworkin RH. What should be the core outcomes in chronic pain clinical trials? Arthritis Research and Therapy 6 (2004) 151-4.

[2] Breivik H, Borchgrevink PC, Allen SM, Roseland LA, Romunstad L, Hals EK, Kvastein G, Stubhaug A. Assessment of pain . British Journal of Anaesthesia 101 (2008) 17-24.

[3] Akah PA, Njike HA. Some pharmacological effects of rhizome aqueous extract of Anchomanes difformis. Fitoterapia 61 (1990) 368-370.

[4] Kerharo J and Bouqet A. Plantes medicinales et toxiques de Coted'ivoire, Haute-volta. Vigot et Freres, Editeurs. Paris 6 (1950) 296.

[5] Atawodi SE, Bulus T, Ibrahim S, Ameh DA, Nok AJ, Mamman M, Galadima M. In vitro trypanocidal effect of methanolic extract of some Nigerian Savanna plants. African Journal of Biotechnology 2 (2003) 317-321.

[6] OECD. Guideline for testing of chemicals No. 425: Acute oral toxicity up and down procedure. Pans: Organization for Economic Cooperation and Development (2001) 1-26.

[7] McLaughlin JL, Chang CJ, Smith D. Bench top bioassay for the discovery of bioactive natural products: An update. In: Atta-ur- Rahman (ed) studies in natural product chemistry. Amsterdam, Elsevier science publication. BV 9 (1991) 383-408.

[8] Shetty SN, Anika SM. Laboratory manual of pharmacology and toxicology. Forth dimension publishers Enugu, Nigeria, (1982) 43 - 47.

[9] Anaga AO, Eke IG, Chah KF. Some pharmacological properties of methanolic extract of Palisota hirsuta leaves. Tropical Veterinarian 27 (2009) 37 - 47.

[10] Dambisya YM, Lee TL, (1995). Effect of L-NAME, L-NMMA and L-arginine on the analgesic effect of morphine in mice. Methods Find. Experimental Clinical Pharmacology 17 (1995) 577-582.

[11] Duarte L,Lorenzetti B, Ferreira S. peripheral analgesia and activation of the nitric oxide cycle GMP pathway. European Journal of pharmacology 186 (1990) $289-293$.

[12] Colleen RM, Josh MB, Diana MB, Jan S, Kari LD, Michael Z, Neil JH, Jayhong AC, David J, Magdalene MM, Christopher MF. TRPA1 mediates formalin-induced pain. Proceedings of National Academy of Science U S A. 14; 104 (2007) 13525-13530.

[13] Panthong A, Norkaew P, Kanjanapothi D, Taesotikul T, Anantachoke N,Reutrakul V. Anti-inflammatory, analgesic and antipyretic activities of the extract of gamboge from Garcinia hanburyi Hook f. Journal of.Ethnopharmacology 111 (2007) 335-340.

[14] Rang HP, Dale MM, Ritter JM. Pharmacology 3rd edition. Churchill Livingstone (1996) $248,669$.

[15] Vaz ZR, Mata LV, Calixto JB. Analgesic effect of herbal medicine Catuma in thermal and chemical models of nociception in mice. Phytotherapy Research 11 (1997)101-106.

[16] Pasternak, GW. Pharmacological mechanisms of opioid analgesics. Clinical Neuropharmacology 16 (1993)1-18.

[17] Porreca F, Mosberg HI, Omnass IR, Burks TF, Cowain A. Supraspinal and spinal potency of selective opioids agonists in the mou se writhing test. Journal of pharmacological Experiment and therapeutics 240 (1987) 890-894.

[18] Bose A, Mondal S, Gupta JK, Ghosh T, Dash GK, Si S. Analgesic antiinflammatory and antipyretic activities of the ethanolic extract and its fractions of Cleome rutidosperma. Fitoterapia 78 (2007) 515-520. 